\title{
Stratiform zinc-lead mineralization in Nasina assemblage rocks of the Yukon-Tanana Upland in east-central Alaska
}

by

Cynthia Dusel-Bacon (U.S. Geological Survey, Menlo Park, Calif.), Jason R. Bressler (WGM, Inc., Anchorage, Alaska), Hidetoshi Takaoka (Sumitomo Metal Mining Company, Vancouver, B.C.), James K. Mortensen (University of British Columbia, Vancouver, B.C.), Douglas H. Oliver (Southern Methodist University, Dallas, Tex.), Joel S. Leventhal (U.S. Geological Survey, Denver, Colo.), Rainer J. Newberry (University of Alaska, Fairbanks, Alaska), and Thomas K. Bundtzen (Pacific Rim Geological Consulting, Fairbanks, Alaska)

Open-File Report 98-340

This report is preliminary and has not been reviewed for conformity with U.S. Geological Survey editorial standards or with the North American Stratigraphic Code. Any use of trade, product, or firm names is for descriptive purposes only and does not imply endorsement by the U.S. Government. 


\section{World Wide Web publication information}

This report is published on line on the World Wide Web at the following URL: http://geopubs.wr.usgs.gov/open-file/of98-340.html and should be cited as follows:

Dusel-Bacon, Cynthia, Bressler, J.R., Takaoka, Hidetoshi, Mortensen, J.K., Oliver, D.H., Leventhal, J.S., Newberry, R.J., and Bundtzen, T.K., 1998, Stratiform zinc-lead mineralization in Nasina assemblage rocks of the Yukon-Tanana Upland in east-central Alaska: U.S. Geological Survey Open-File Report 98-340 (World Wide Web URL, http://geopubs.wr.usgs.gov/open-file/of98-340.html).

\section{Introduction}

The Yukon-Tanana Upland of east-central Alaska and Yukon comprises thrust sheets of ductilely deformed metasedimentary and metaigneous rocks of uncertain age and origin that are overlain by klippen of weakly metamorphosed oceanic rocks of the Seventymile-Slide Mountain terrane, and intruded by post-kinematic Early Jurassic, Cretaceous and Tertiary granitoids.

Metamorphosed continental margin strata in the Yukon-Tanana Upland of east-central Alaska are thought to be correlative, on the basis of stratigraphic similarities and sparse Mississippian U-Pb zircon and fossil ages (Mortensen, 1992), with middle Paleozoic metasedimentary and metavolcanic rocks in the eastern Alaska Range and in western and southeastern Yukon. Furthermore, rocks in the northern Yukon-Tanana Upland may correlate across the Tintina fault with unmetamorphosed counterparts in the Selwyn Basin (Murphy and Abbott, 1995).

Volcanic-hosted (VMS) and sedimentary exhalative (sedex) massive sulfide occurrences are widely reported for these other areas (green-colored unit of fig. 1) but, as yet, have not been documented in the Alaskan part of the Yukon-Tanana Upland. Recent discoveries of VMS deposits in Devono-Mississippian metavolcanic rocks in the Finlayson Lake area of southeastern Yukon (Hunt, 1997) have increased the potential for finding VMS deposits in rocks of similar lithology and age in the Yukon-Tanana Upland of Alaska. Restoration of $450 \mathrm{~km}$ of early Tertiary dextral movement along the Tintina fault juxtaposes these two areas. 


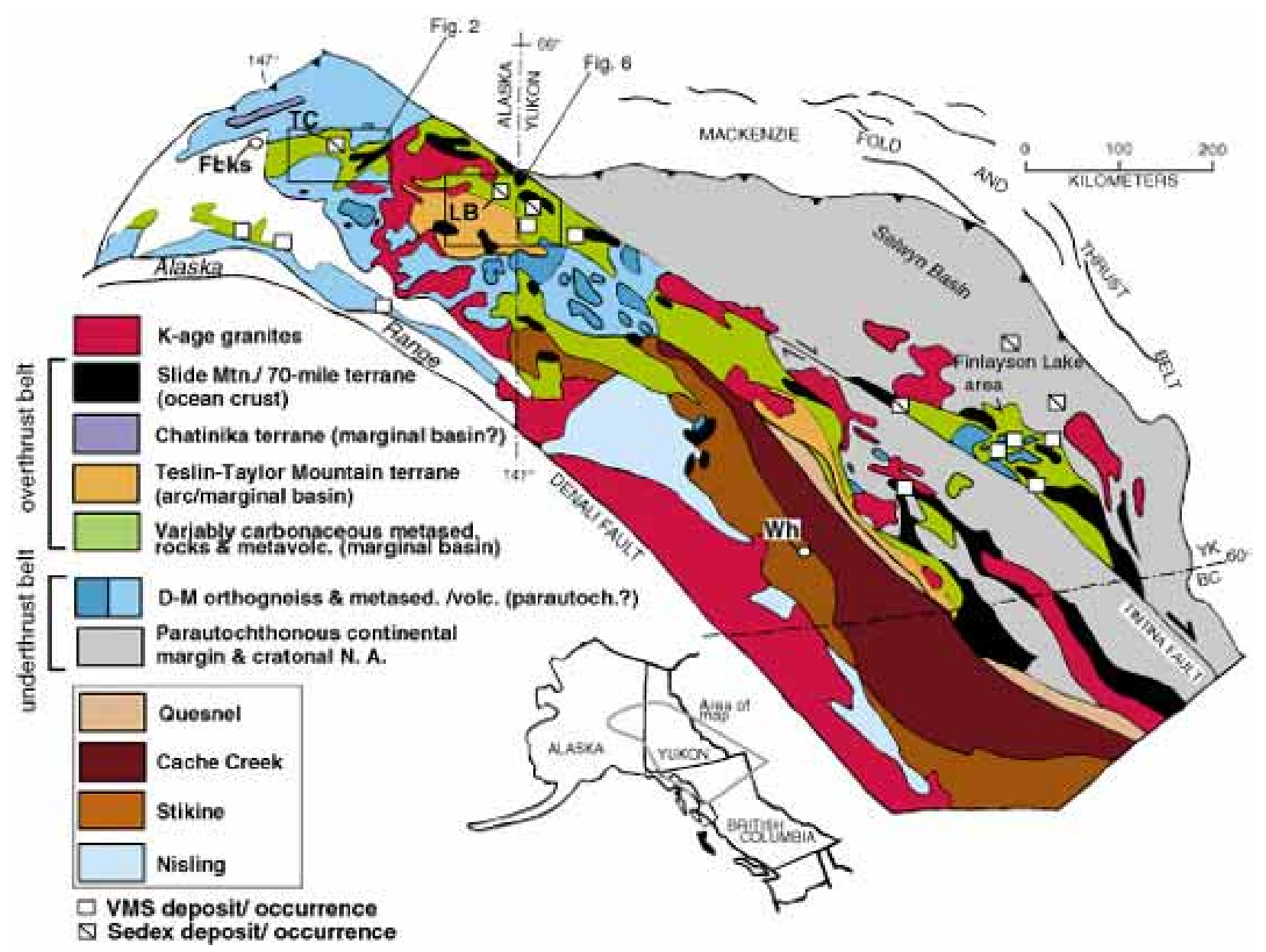

Figure 1. Tectonic elements of the northern Cordillera showing location of VMS and sedex deposits and occurrences within greenschist-facies variably carbonaceous metasedimentary rocks and associated metavolcanic rocks. Fbks, Fairbanks; Wh, Whitehorse; TC, Teuchet Creek drill site; LB, Liberty area of zinc mineralization.

\section{This study}

We report here the initial results of a study initiated by the U.S. Geological Survey (USGS), in cooperation with geologists from industry and academia, aimed at characterizing the mode of occurrence, age and petrogenesis of stratiform base-metal occurrences in the YukonTanana Upland of east-central Alaska (Dusel-Bacon and others, 1997, 1998a,b). We report on our ongoing investigation in two of the areas under study:

1) the Chena Slate Belt (CSB) located $110 \mathrm{~km}$ east of Fairbanks (fig. 2), and

2) the Liberty area located $200 \mathrm{~km}$ farther east near the Alaska-Yukon border (fig. 6).

\section{Chena Slate Belt}

\section{Identification and exploration of sediment-hosted base-metal targets}

The Chena Slate Belt is an informal name, coined by WGM, Inc., for a 75-km-long belt of siliceous and carbonaceous black quartzite, slate, and phyllite (grey-colored unit, fig. 2) in the northern Big Delta quadrangle. USGS reconnaissance mapping and rock and stream-sediment 
geochemical studies in the late 1970's indicated a potential for sediment-hosted base-metal deposits in the belt (Menzie and Foster, 1978). WGM, Inc., conducted exploration in this belt intermittently between 1981 and 1994. Stream silt geochemical data collected in the belt identified a 30-km-long belt of strongly anomalous $\mathrm{Zn}$ values. Poor exposure of the recessively weathering carbonaceous lithology necessitated a follow-up program, begun in 1991 on behalf of Sumitomo Metal Mining Company, consisting of soil and rock geochemical surveys, gravity surveys, and airborne and horizontal-loop EM surveys. Results from these surveys delineated three $\mathrm{Zn}-\mathrm{Pb}$ targets in the vicinity of Teuchet Creek ( $\boldsymbol{T C}$, fig. 2). Eight core holes totaling 1,600 m drilled as preliminary tests of the targets revealed a section comprising $30 \mathrm{~m}$ of tan sericitic phyllite underlain by at least $550 \mathrm{~m}$ of interlayered gray to black siliceous phyllite and quartzite. Twenty-five $\mathrm{km}$ to the west, another base-metal target was drilled in carbonaceous and calcareous slate at Drone Creek $(\boldsymbol{D C}$, fig. 2).

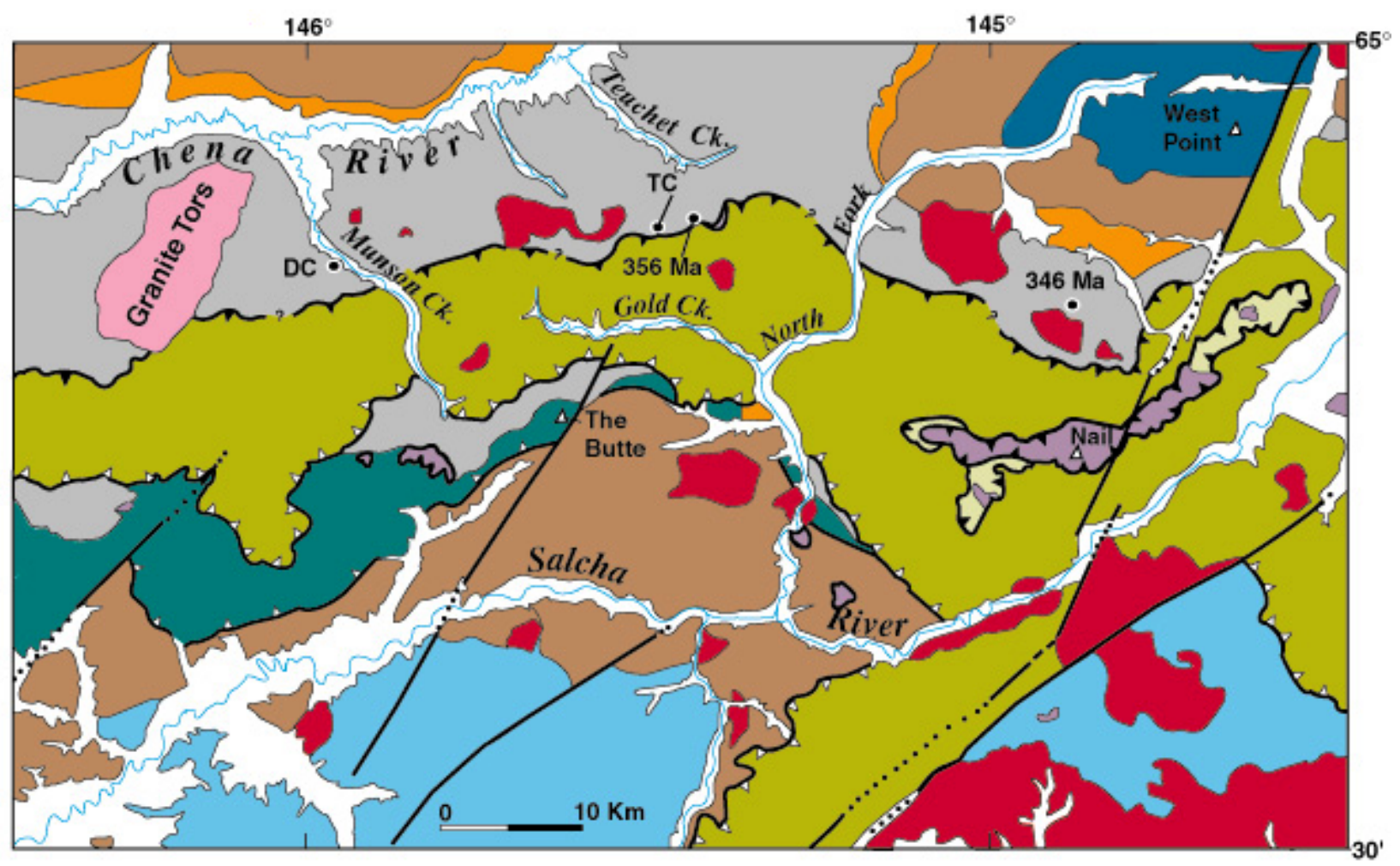




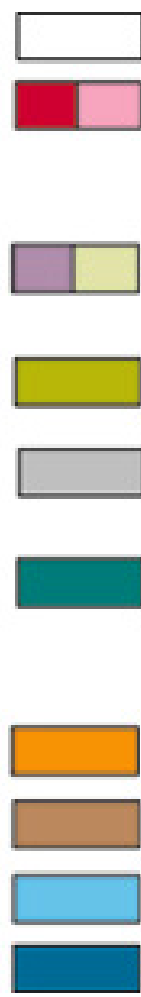

SURFICIAL DEPOSITS (Q)

POSTMETAMORPHIC GRANITOIDS (K)\&(T)

STRUCTURALLY HIGHER ROCKS

PERIDOTITE, GREENSTONE, METALIMESTONE, METACHERT, AND METASEDIMENTARY ROCKS ( $\mathrm{K}, \mathrm{P}, \mathrm{M}$ ) (SEVENTYMILE TERRANE)

GREENSCHIST-FACIES SEMISCHIST, PHYLLITE, QUARTZITE, MARBLE AND GREENSTONE

CARBONACEOUS QUARTZITE \& PHYLLITE, FELSIC AND MAFIC METAVOLCANICS (DM) (NASINA ASSEMBLAGE)

QUARTZOFELDSPATHIC MYLONITE SCHIST AND GNEISS (mP)

STRUCTURALLY LOWER ROCKS

CALCAREOUS PHYLLITE AND MARBLE

AMPHIBOLITE-FACIES PELTIC SCHIST, QUARTZITE, MARBLE AND AMPHIBOLITE

SILLIMANITE GNEISS, QUARTZITE AND MARBLE

QUARTZITE, MARBLE, PELITIC SCHIST \& GRANITOIDS

Figure 2. Geologic map of the northern Big Delta quadrangle (modified from Weber and others, 1978) showing location of Teuchet Creek (TC) and Drone Creek (DC) drill sites and U-Pb zircon crystallization ages of felsic metavolcanic rocks.

\section{Results from drilling}

The best mineralized target at the Teuchet Creek Property yielded intersections of up to 5 percent disseminated and foliation-parallel pyrite, sphalerite and galena in carbonaceous phyllite and quartzite over intervals of $18 \mathrm{~m}$ to $61 \mathrm{~m}$. Mineralized sections included $4.6 \mathrm{~m}$ at 0.92 percent $\mathrm{Zn}$ and 0.32 percent $\mathrm{Pb}$, with $12 \mathrm{~cm}$ at 10.1 percent $\mathrm{Zn}, 3.6$ percent $\mathrm{Pb}$, and $38 \mathrm{~g} / \mathrm{t} \mathrm{Ag}$. Pyrite occurs locally in massive layers up to $52 \mathrm{~cm}$ thick with bands of red-brown sphalerite, galena and pyrite up to $12 \mathrm{~cm}$ thick (figs. $3 A$ and $3 B$ ). Drilling at the Drone Creek Property revealed approximately $45 \mathrm{~m}$ of sulfide-bearing zones, including a $17 \mathrm{~m}$ interval of black, very carbonaceous slate with laminae of sphalerite, galena, pyrite and pyrrhotite with 5-7 percent total sulfides. A 1.2-m thick sphalerite-rich interval from which the sample shown in figs. $3 C$ and $3 D$ was taken averaged 1.88 percent $\mathrm{Zn}, 820$ parts per million (ppm) $\mathrm{Pb}$, and $4.4 \mathrm{~g} / \mathrm{t} \mathrm{Ag}$. 


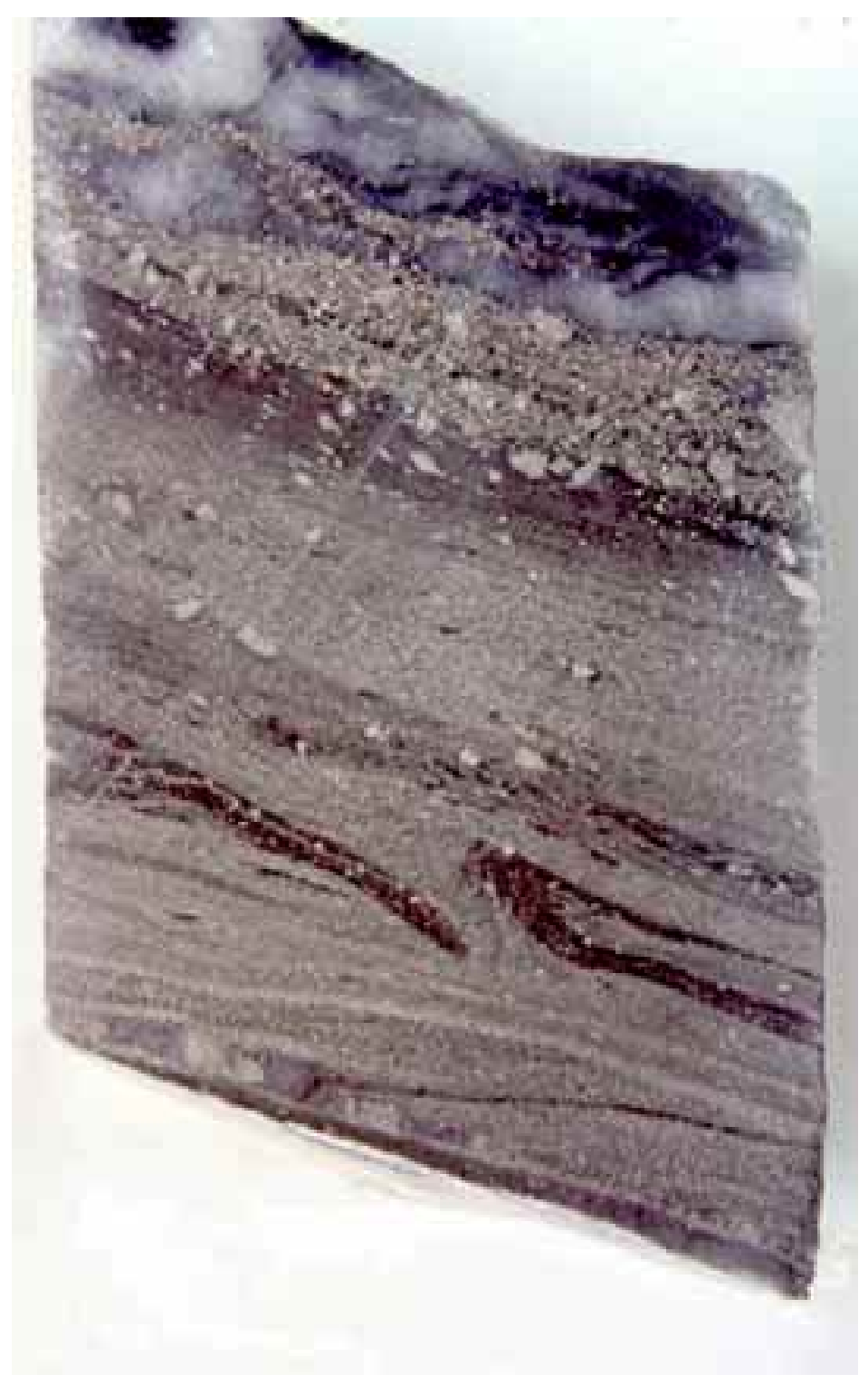

Figure 3A. Finely laminated pyrite in drill core from Teuchet Creek. Note larger pyrite porphyroblasts and folding visible in carbonaceous layers. Sample TC4-673.4'; core is $4.8 \mathrm{~cm}$ wide. 


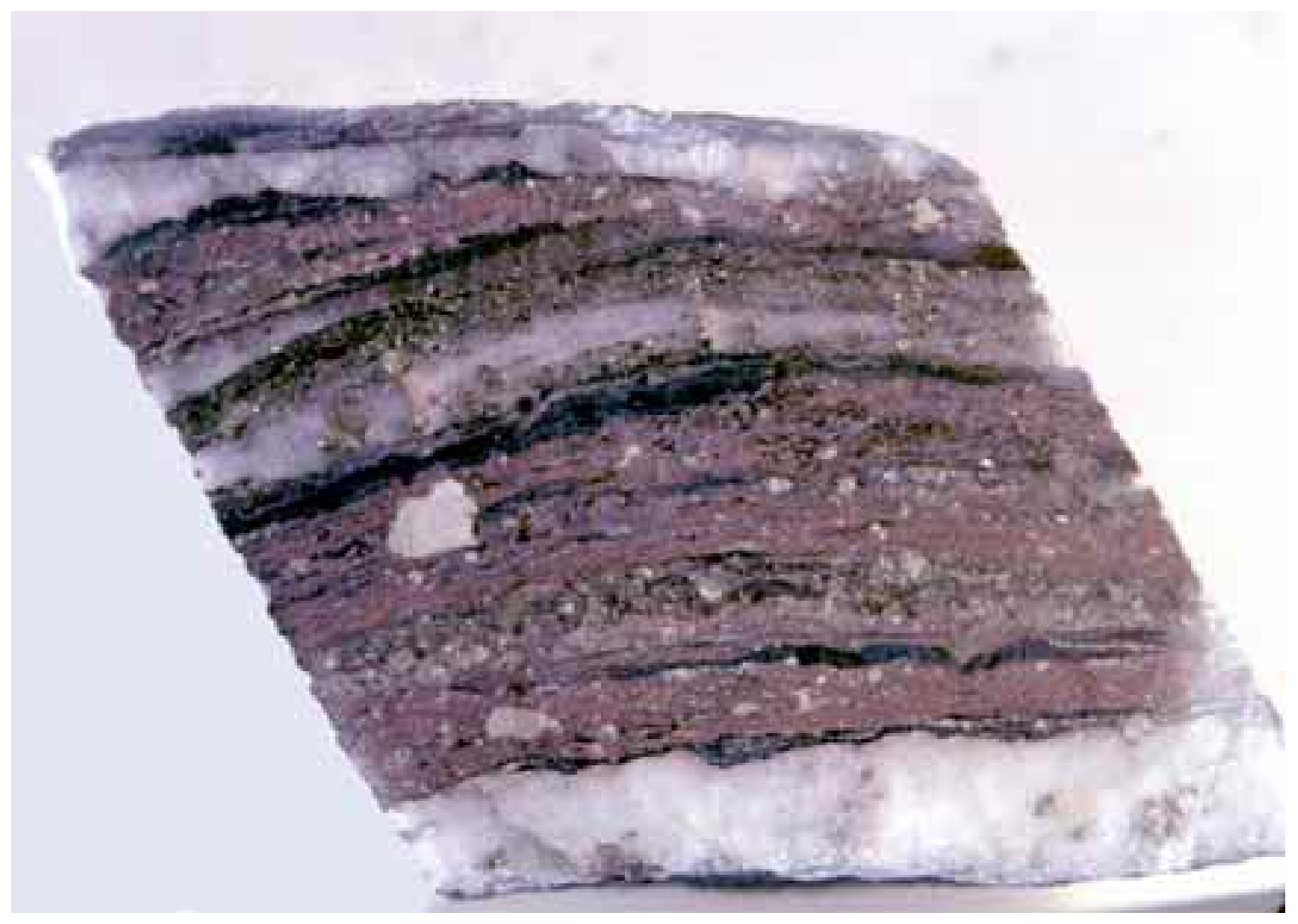

Figure 3B. Sphalerite-rich interval in drill core from Teuchet Creek. Note threadlike wisps of silvery galena, brassy pyrite porphyroblasts, and concordant quartz veins. Sample TC4-670'; core is $4.8 \mathrm{~cm}$ wide. 


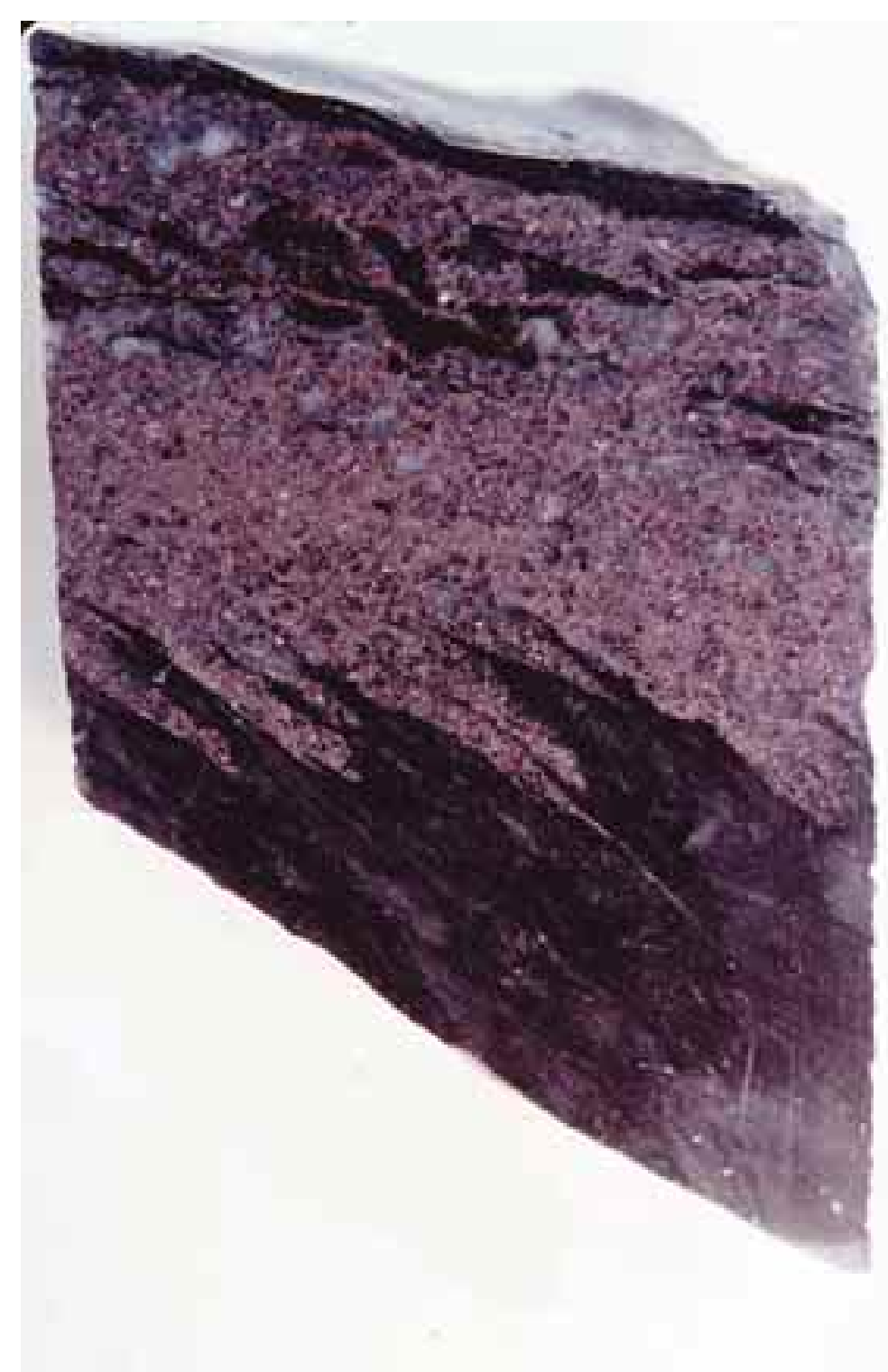

Figure 3C. Five-cm thick layer of folded sphalerite and quartz in drill core from Drone Creek. Sample DC3-277'; core is $4.8 \mathrm{~cm}$ wide. 


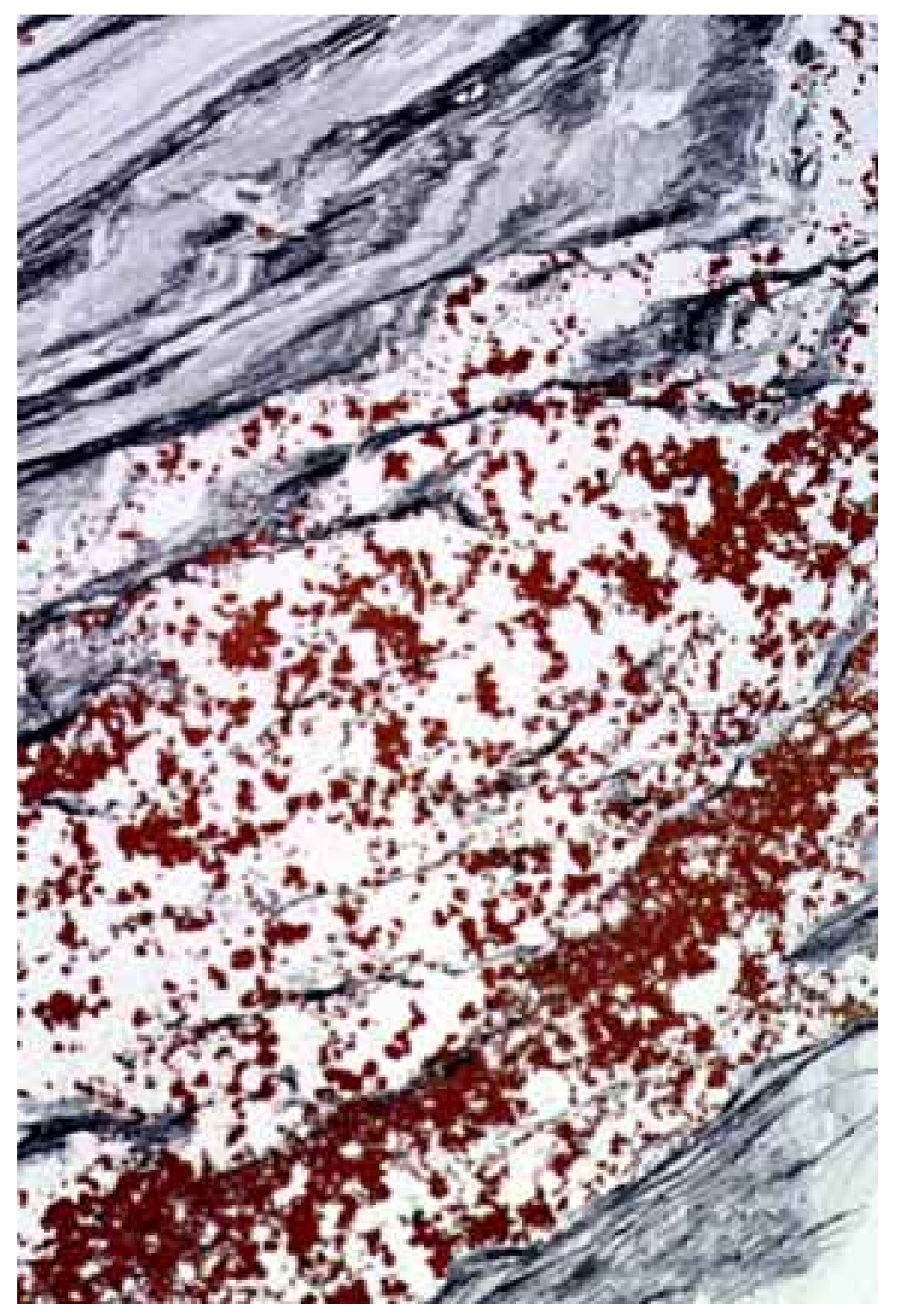

Figure 3D. Photograph of entire thin section made from core shown in 3C. Note concentration of sphalerite (red-brown) in quartz-rich, graphite-poor layer. Height of photo is about $35 \mathrm{~mm}$.

\section{Sulfide textures and mineralogy}

Primary sedimentary features in the carbonaceous rocks have been obliterated by complex ductile shearing, folding, and low- to medium-grade metamorphism. Deformation fabrics in the sulfides indicate that mineralization pre-dated regional metamorphism. Early formed, near vertical, quartz veining is truncated along low-angle shear planes along which pyrite is commonly concentrated (fig. 4A). Pyrite precipitation both preceded (fig. 4B) and followed (fig. 4C) quartz veining and shearing episodes. Pyrite occurs as laminae of subhedral cubes and as larger porphyroblasts which have been partially comminuted into fine fragments (fig. 5A). Sphalerite (about 84 percent $\mathrm{ZnS}$ ) occurs as anhedral lenses and galena forms interstitial fillings in areas high in pyrite and sphalerite (figs. $5 A$ and $5 B$ ). Boulangerite $(\mathrm{PbSbS})$ and selenium-rich galena $(\mathrm{PbS}$ PbSe solid solution) (fig. 5C) occur along with galena in one interval of TC5 core. Chalcopyrite, pyrrhotite, and arsenopyrite are present in minor amounts. 
Dusel-Bacon and others, 1998, USGS Open-File Report 98-340

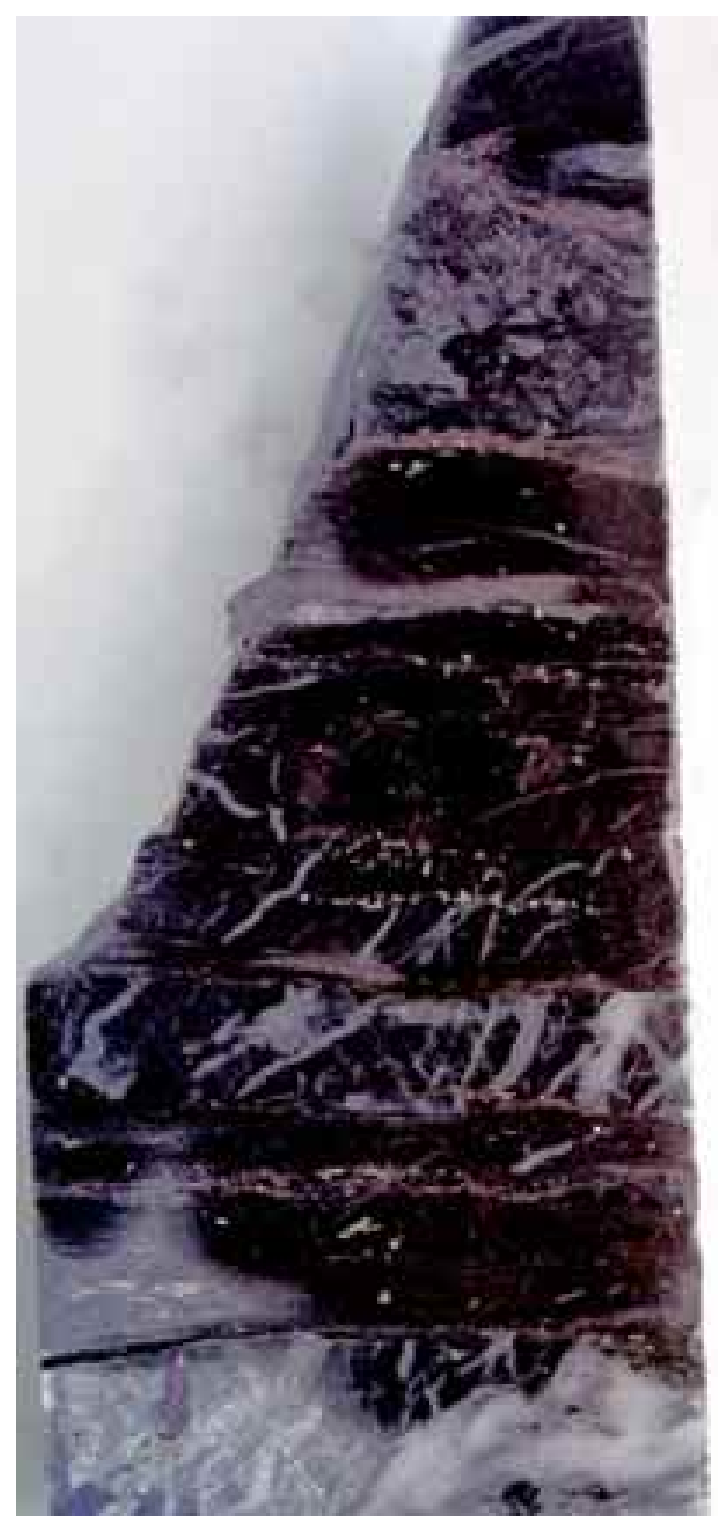

Figure 4A. Siliceous black slate showing truncation of vertical quartz veins along low-angle shear planes. Note laminae of golden pyrite and reddish sphalerite (top of photo). Sample TC5638 '; core is $4.8 \mathrm{~cm}$ wide. 
Dusel-Bacon and others, 1998, USGS Open-File Report 98-340

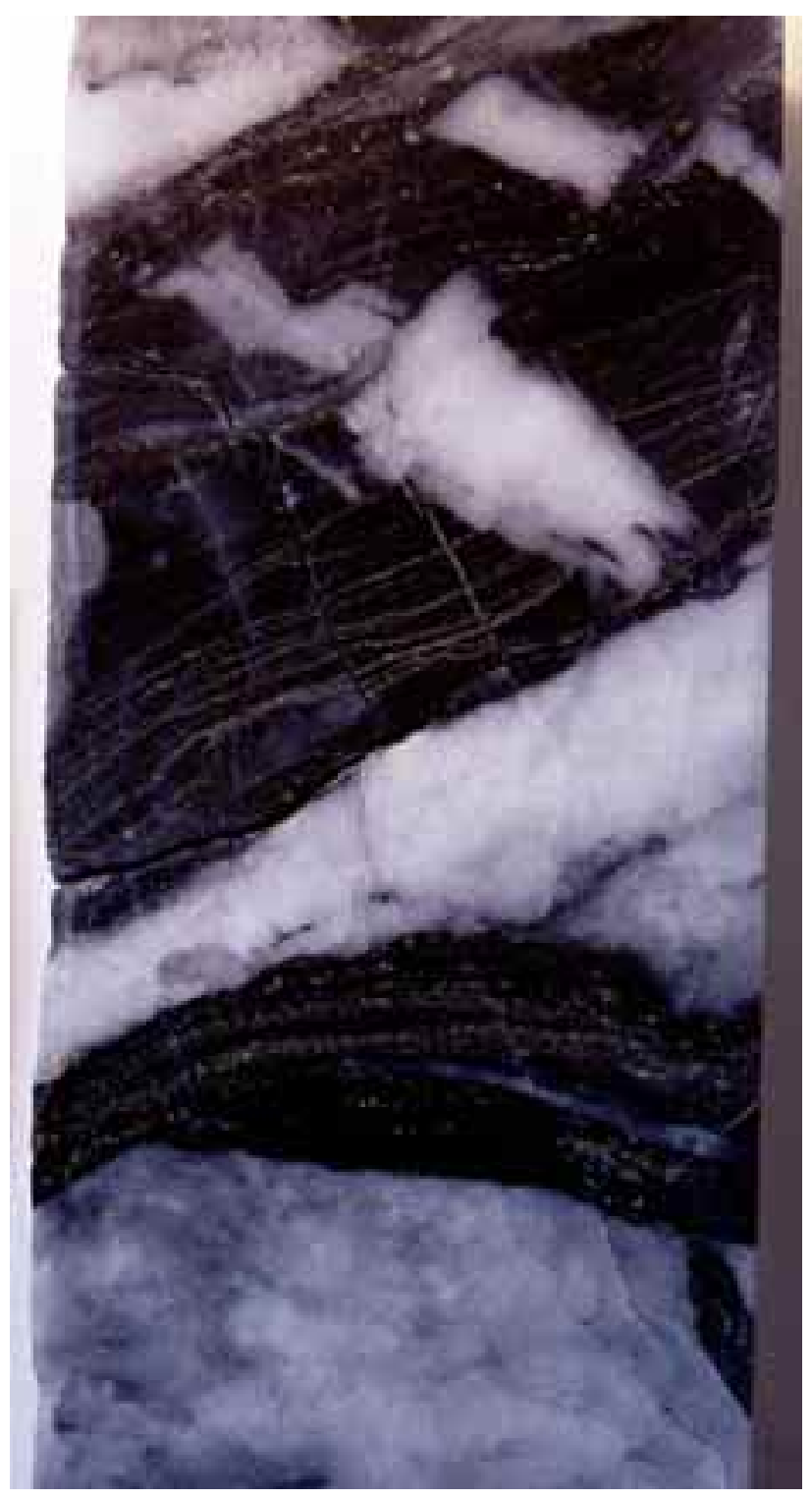

Figure 4B. Pyrite laminae in graphitic slate cut by early quartz veins and concordant to later ones. Sample TC4-690'; core is $4.8 \mathrm{~cm}$ wide. 


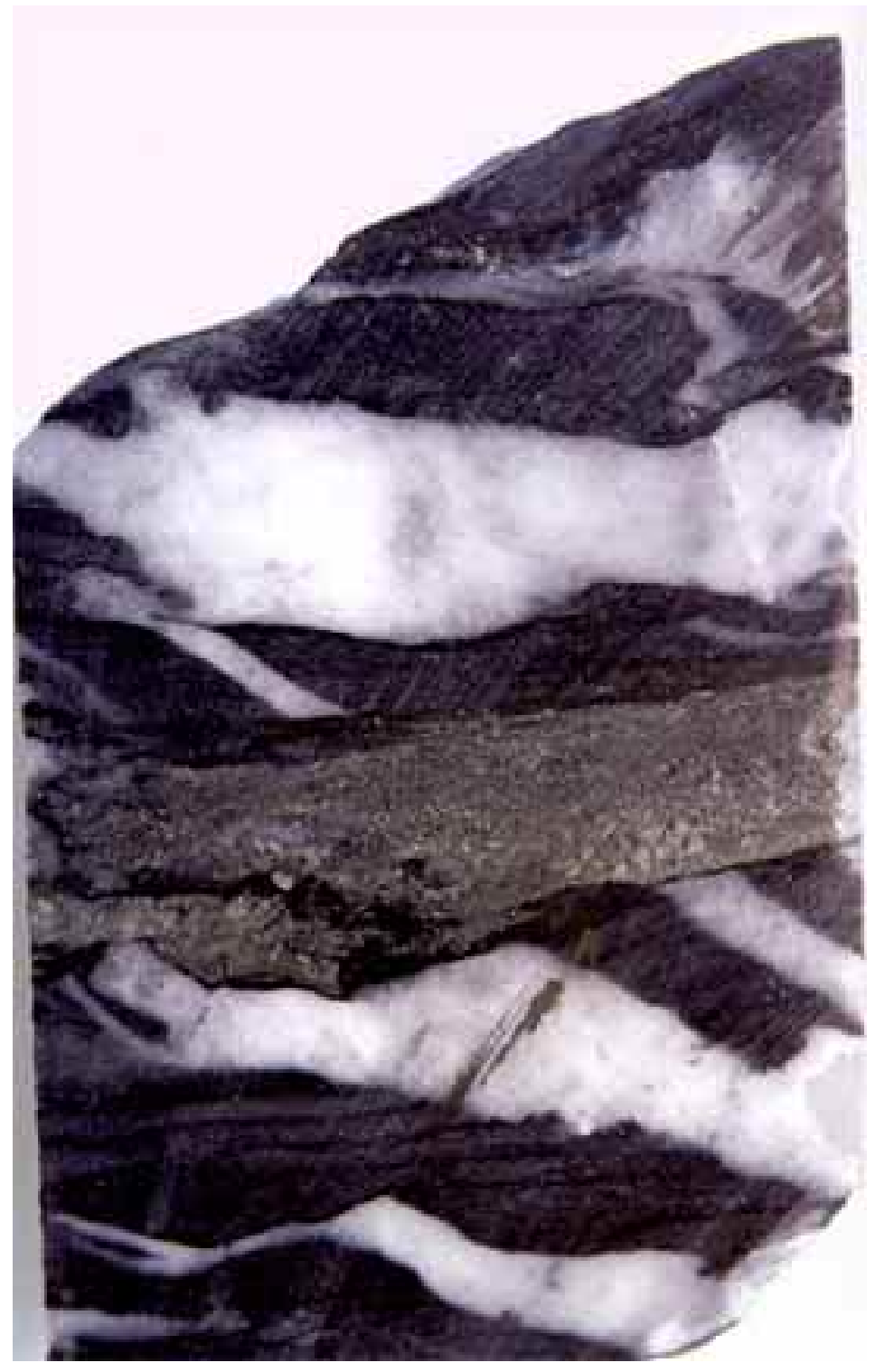

Figure 4C. Pyrite concentrated within shear band that truncates quartz veins in graphitic slate. Sample TC4-691'; core is $4.8 \mathrm{~cm}$ wide. 


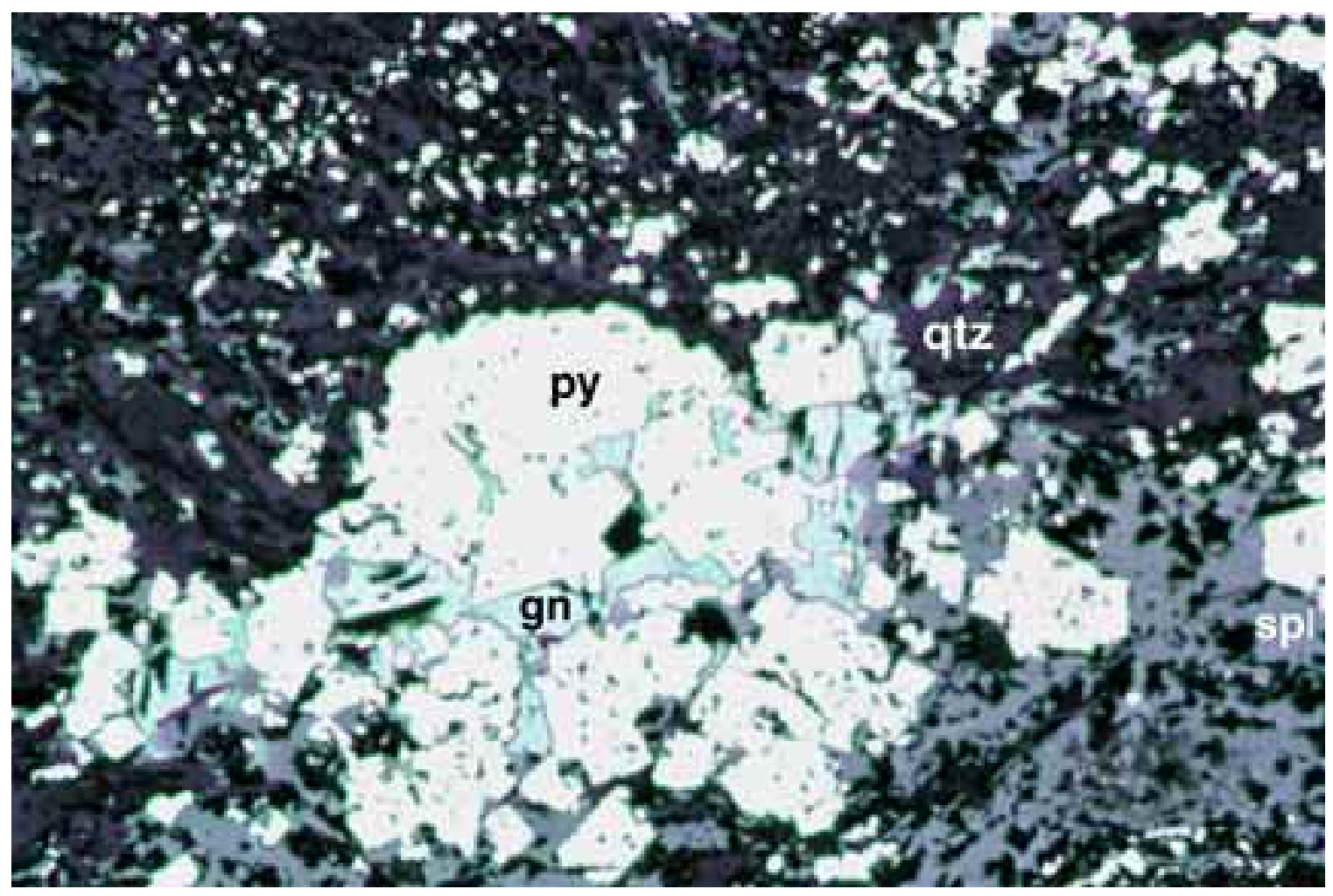

Figure 5A. Reflected light (plane polarized) photomicrograph showing comminution of pyrite porphyroblast (top of photo) to form disseminated pyrite fragments. Note cleavage pits in interstitial galena. Sample TC5-400'; width of photo $1.72 \mathrm{~mm}$. 


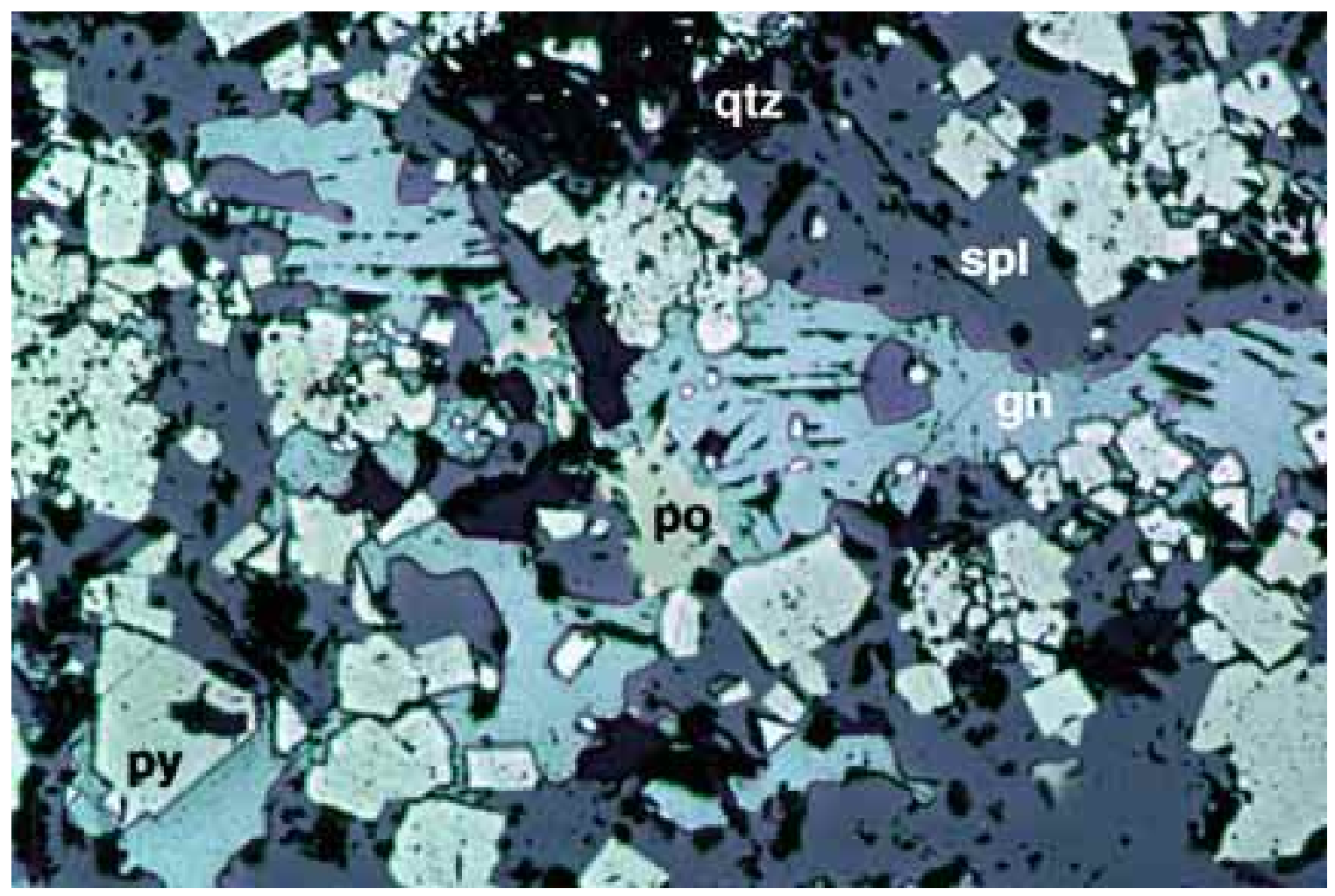

Figure 5B. Reflected light (plane polarized) photomicrograph showing typical texture of sulfiderich intervals with subidiomorphic pyrite, interstitial galena, and amorphous sphalerite. Pyrrhotite occurs in trace amounts. Sample TC4-674.6'; width of photo $1.72 \mathrm{~mm}$. 


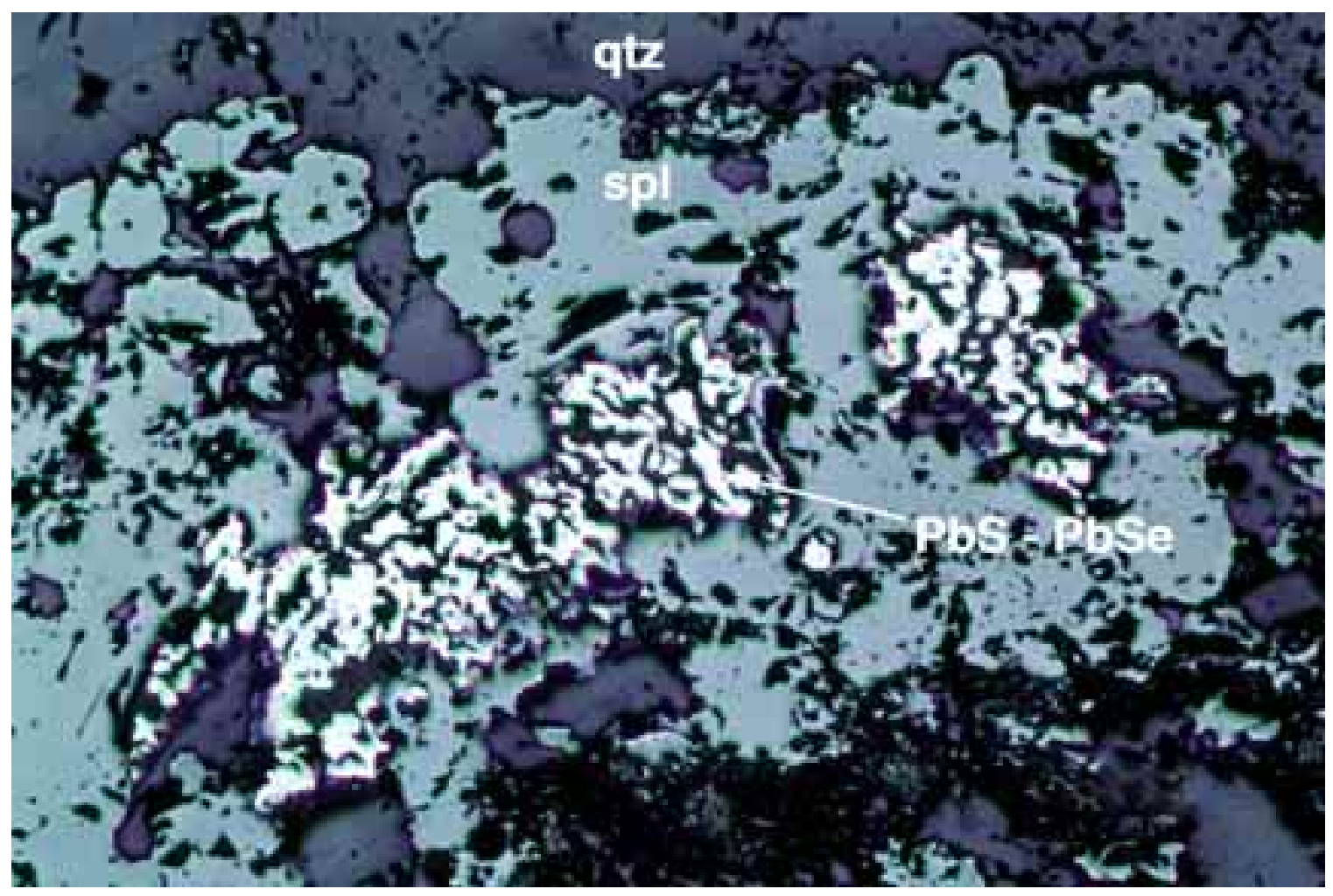

Figure 5C. Reflected light (plane polarized) photomicrograph showing wormy selenium-rich galena within a sphalerite layer. Amount of Se substituted for $\mathrm{S}$ in sample ranges from 4 to 37 atom percent. Sample TC5-638'; width of photo $1.72 \mathrm{~mm}$.

\section{Liberty area}

Stratiform $\mathrm{Zn}-\mathrm{Pb}-\mathrm{Ag}$ mineral occurrences are hosted in carbonaceous schist, quartzite, and possible felsic metavolcanic rocks in a poorly exposed $150 \mathrm{~km}^{2}$ area near Liberty in the southeastern Eagle quadrangle of Alaska and in adjacent parts of Yukon (fig. 6). In Alaska, this area is part of the holdings of the Doyon, Limited, Native Corporation. Most of the mineralization occurs in rocks proposed as correlatives of the Devono-Mississippian Nasina assemblage (Mortensen, 1988; Foster, 1992). 

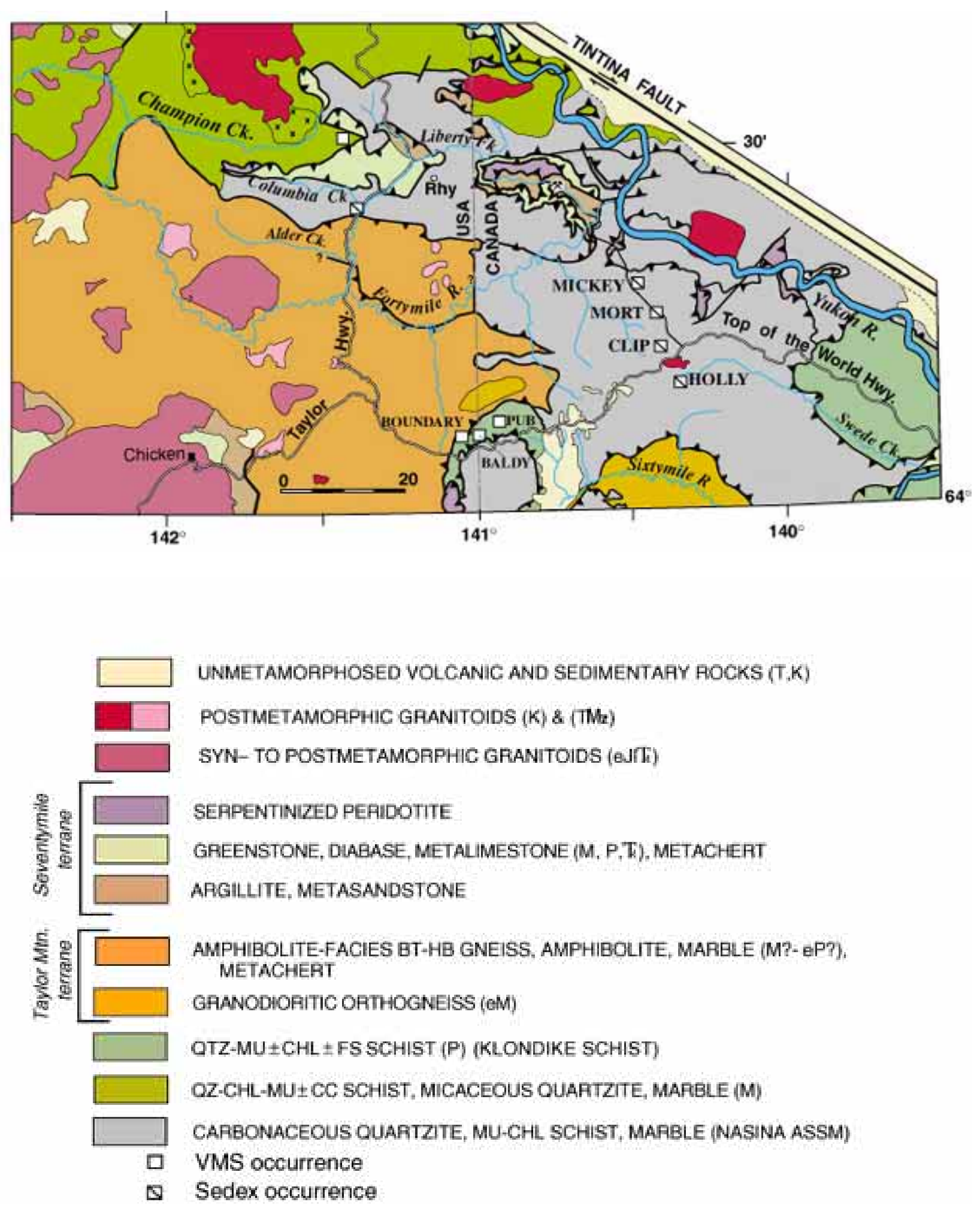

Figure 6. Simplified geologic map of the Liberty area (modified from Foster, 1992, and Mortensen, 1988). 


\section{Newly identified zinc mineralization in Nasina Quartzite}

Three previously unreported localities of sphalerite-bearing quartzite were discovered during this study along a three-km stretch of the Taylor Highway near the mouth of Columbia Creek. Carbonaceous quartzite is the dominant lithology at all three localities but mineralization was only observed in carbon-free or carbon-poor quartzite (metachert or exhalite?). At the southernmost and middle localities (borrow pits), dark foliaform laminae of reddish-amber sphalerite >>pyrite > galena >chalcopyrite occur within scattered blocks of buff-colored, celsian (barium silicate)-bearing quartzite (94-96 percent $\mathrm{SiO}_{2}$ ) (figs. $7 A$ and $7 B$ ). Strained, elongate quartz grains and thin folia of tabular celsian define a penetrative fabric. Celsian-bearing quartzites from both sites are high in $\mathrm{Ba}$ (1.6 and 3.6 percent), $\mathrm{Zn}$ (1.8 and 2.7 percent), and $\mathrm{Pb}$ (3,980 and $1,040 \mathrm{ppm})$.

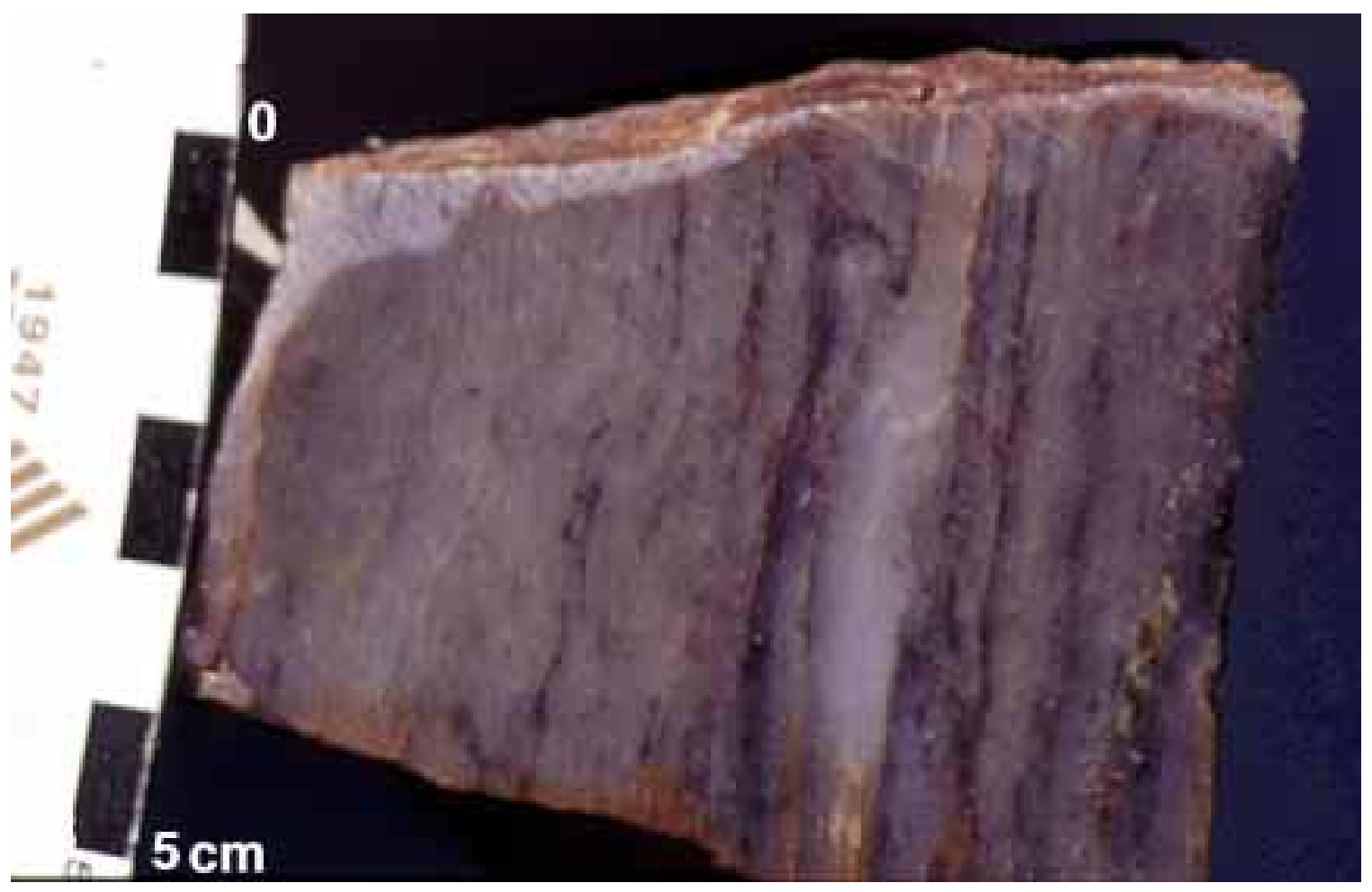

Figure 7A. Sample of celsian quartzite with thin lenses and laminae of sphalerite (dark gray in photo). Sample 96ADb 32c. 


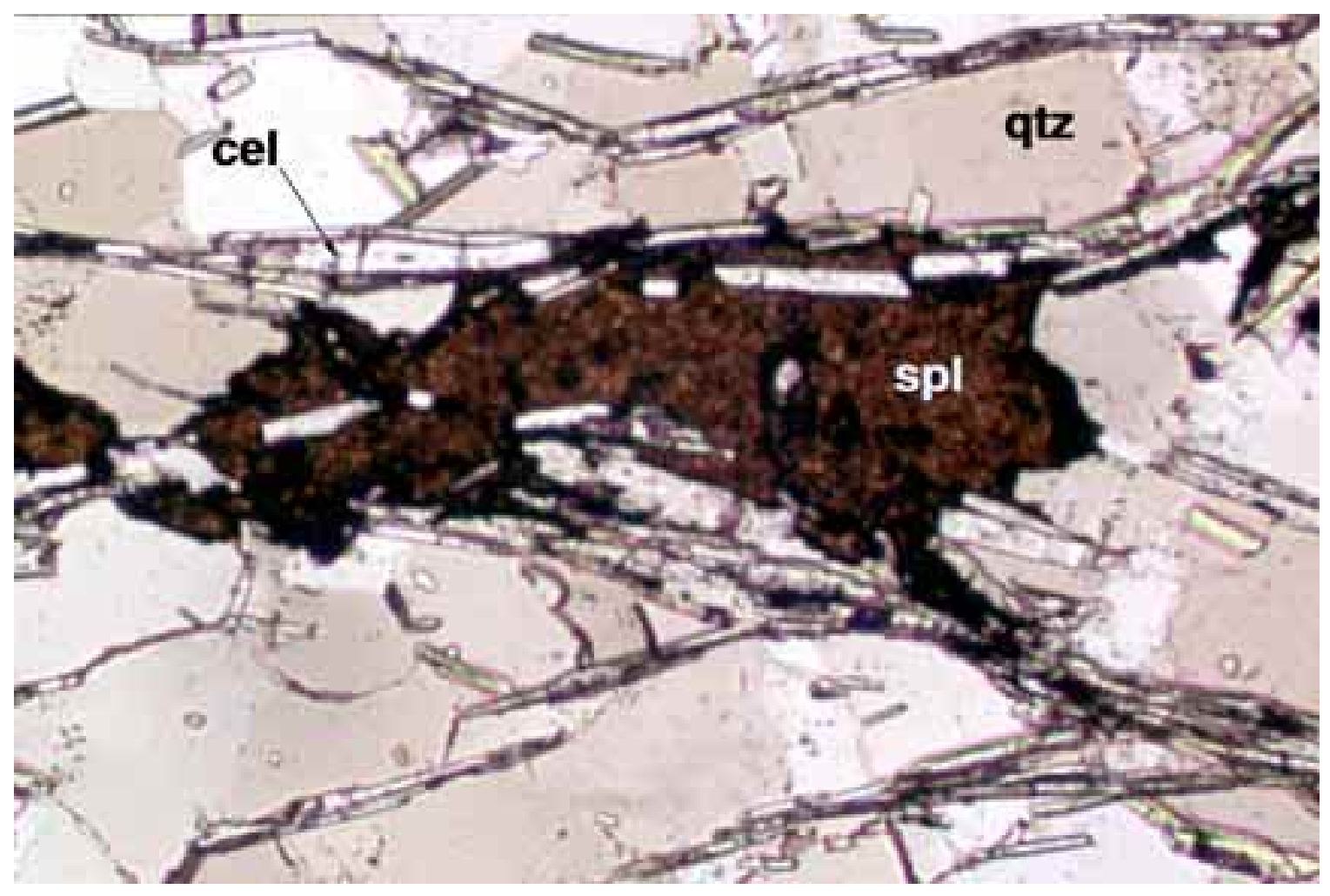

Figure 7B. Transmitted light (plane polarized) photomicrograph of sample shown in fig. 7A showing sphalerite lenses and colorless, prismatic celsian (a barium silicate). Width of photo 0.86 $\mathrm{mm}$.

The northernmost locality consists of variably rusty-weathering, tan to pale gray, slightly muscovitic and carbonaceous quartzite (88 percent $\mathrm{SiO}_{2}$ ) exposed in outcrop and landslide debris just east of the mouth of Columbia Creek. Interlayered with the quartzite are 10-20 cm-thick layers of more muscovite-rich quartzite including some layers of muscovite schist. These layers may have originated as felsic tuffs. The sulfides (amber-brown sphalerite>>galena, chalcopyrite) occur within the quartzite in discontinuous lenses $1-2 \mathrm{~cm}$ thick (fig.8). 


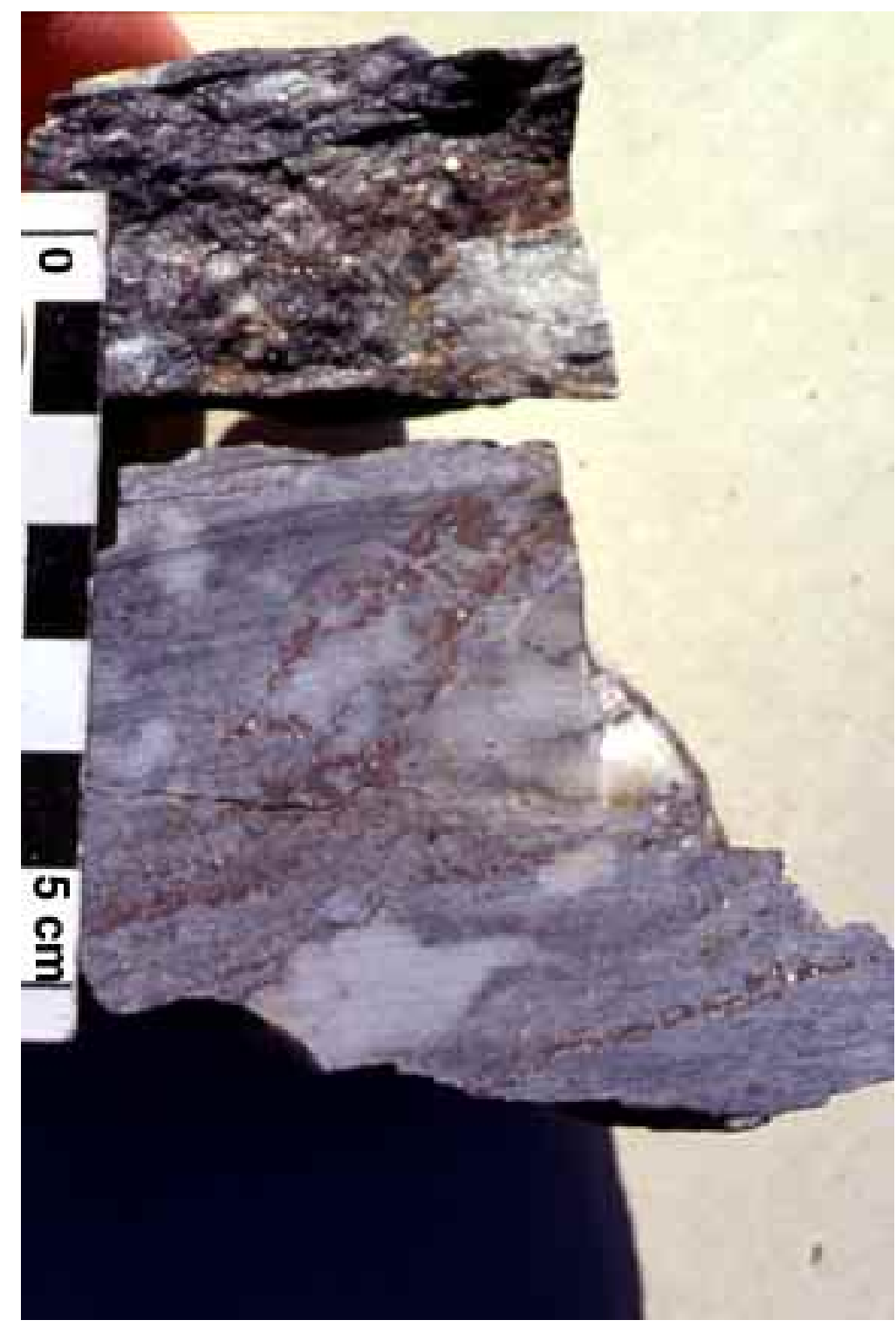

Figure 8. This grab sample of sphalerite-bearing quartzite yielded 8.1 percent $\mathrm{Zn}, 100 \mathrm{ppm} \mathrm{Cd}$, 38 parts per billion (ppb) Au, and 132 ppm Hg. Sample 96ADb 63.

\section{Quartzite-hosted mineralization spans border}

Four showings of stratiform $\mathrm{Pb}-\mathrm{Zn}$ mineralization, similar to those in the Liberty area, occur in Nasina assemblage quartzite in the Dawson 116C quadrangle of Yukon (Mortensen, 1988; Hunt, 1997). At one of these showings (MORT), 1-3 mm-thick laminae of galena or cerussite \pm sphalerite are present in buff-colored muscovitic quartzite interlayered with muscovite schist (figs. $9 A$ and $9 B)$. 


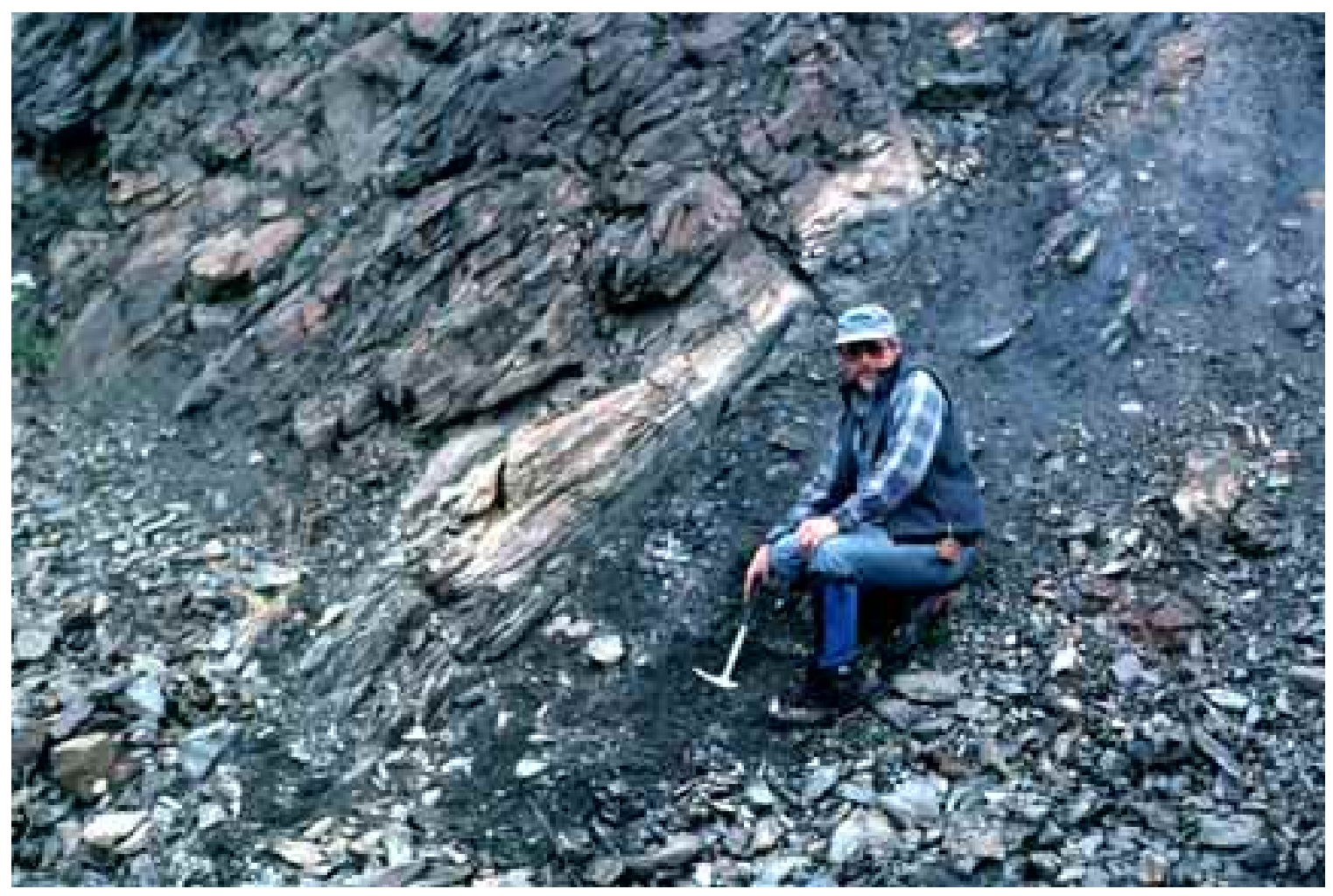

Figure 9A. Jim Mortensen poses at the MORT occurrence (location shown on fig. 6). Sample of fig. 9B was collected from light-colored, folded quartz-rich layer. 


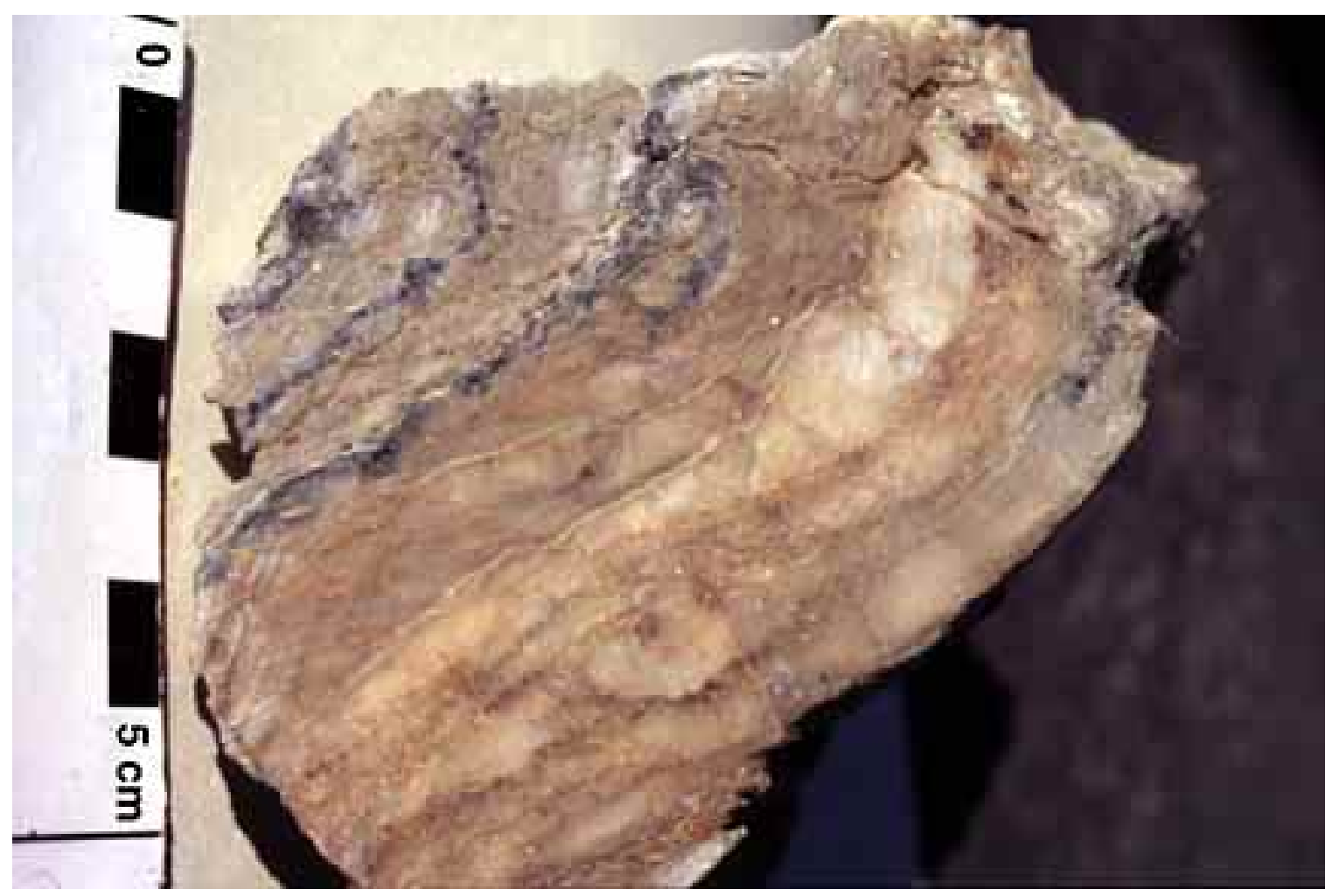

Figure 9B. This sample of cerussite-bearing quartzite yielded 4.3 percent $\mathrm{Pb}, 54 \mathrm{~g} / \mathrm{t} \mathrm{Ag}$, and 60 ppb Au. Sample 96ADb41b.

\section{Lead Creek prospect hosts base- and precious-metal mineralization of unknown age}

The Lead Creek prospect, so named because of the discovery by WGM, Inc., of high Pb, $\mathrm{Zn}$, and Ag values in silt samples from a south-flowing tributary of Columbia Creek, is currently being drilled as part of an exploration program conducted by WGM, Inc., on behalf of Ventures Resource Alaska. The prospect is underlain by a regionally and contact-metamorphosed, relatively undeformed section of carbonaceous schist, quartz-mica schist, pyritic metachert, felsic metatuff, and marble. Protolith ages for the host rocks may be Triassic, Permian, or Devonian and Mississippian. EM conductors and $\mathrm{Pb}$ and $\mathrm{Ag}$ soil anomalies occur in an area underlain by carbonaceous schist containing siliceous nodules and quartz-galena veins. Most siliceous nodules contain <3.7 percent $\mathrm{Pb}$ and $196 \mathrm{~g} / \mathrm{t} \mathrm{Ag} \mathrm{(Schmidt,} \mathrm{1997).} \mathrm{A} 2.5 \mathrm{~m}$-long trench sample of carbonaceous schist contained 1.9 percent $\mathrm{Pb}$ and $72 \mathrm{~g} / \mathrm{t} \mathrm{Ag}$ and a sample of a feldspar porphyry dike contained 1,309 ppm Pb and 2,450 ppm As (U.S. Bureau of Mines, 1995). Sampling at the prospect during the present study yielded a sample of pyrite-bearing carbonaceous quartzite that contained >10,000 ppm As and $170 \mathrm{ppb} \mathrm{Au}$ and a highly mineralized and oxidized sample displaying gray and yellow banding (fig. 10). 


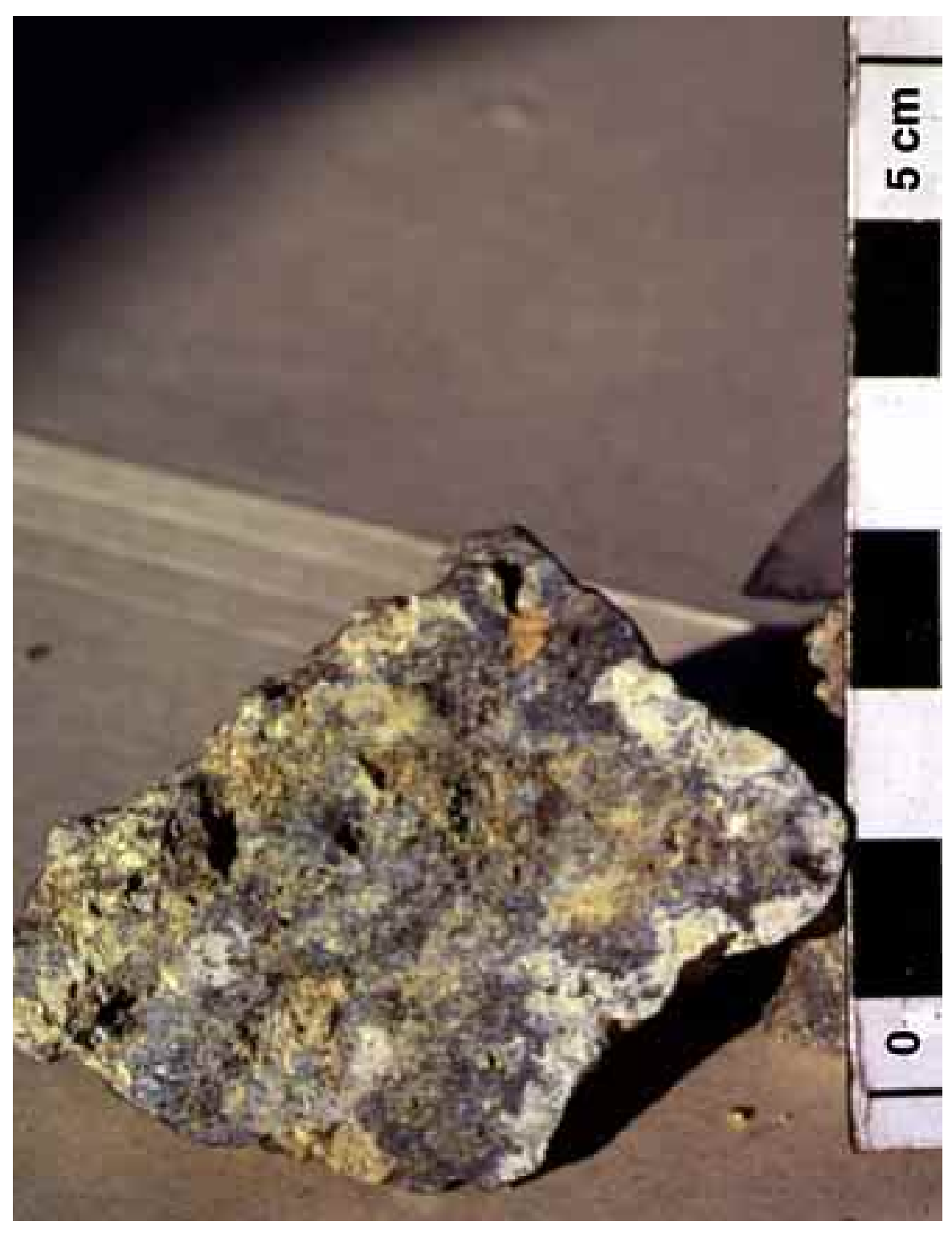

Figure 10. This supergene grab sample from the Lead Creek prospect yielded 2,330 ppb $\mathrm{Au}$, $2126 \mathrm{~g} / \mathrm{t} \mathrm{Ag},>10,000 \mathrm{ppm} \mathrm{As},>100 \mathrm{ppm} \mathrm{Cd}, 1,420 \mathrm{ppm} \mathrm{Cu}, 10.8$ percent $\mathrm{Pb}$, and >10,000 ppm Sb. Sample $96 \mathrm{ADb} 49$.

\section{Newly dated Permian metarhyolite expands potential for VMS deposits}

Weakly metamorphosed and deformed pyritic rhyolite tuff (fig. 11) crops out $13 \mathrm{~km}$ northeast of the mouth of Columbia Creek in an area formerly mapped as part of the Nasina assemblage. A U-Pb zircon age determined in this study indicates a Permian $(256.6 \pm 1 \mathrm{Ma})$ crystallization age for the rhyolite suggesting correlation with the Klondike Schist. Several VMS occurrences are hosted in Klondike Schist near Boundary (fig. 6) (Mortensen, 1988), $45 \mathrm{~km}$ to the south, enhancing the potential for similar-aged deposits in the Liberty area. 


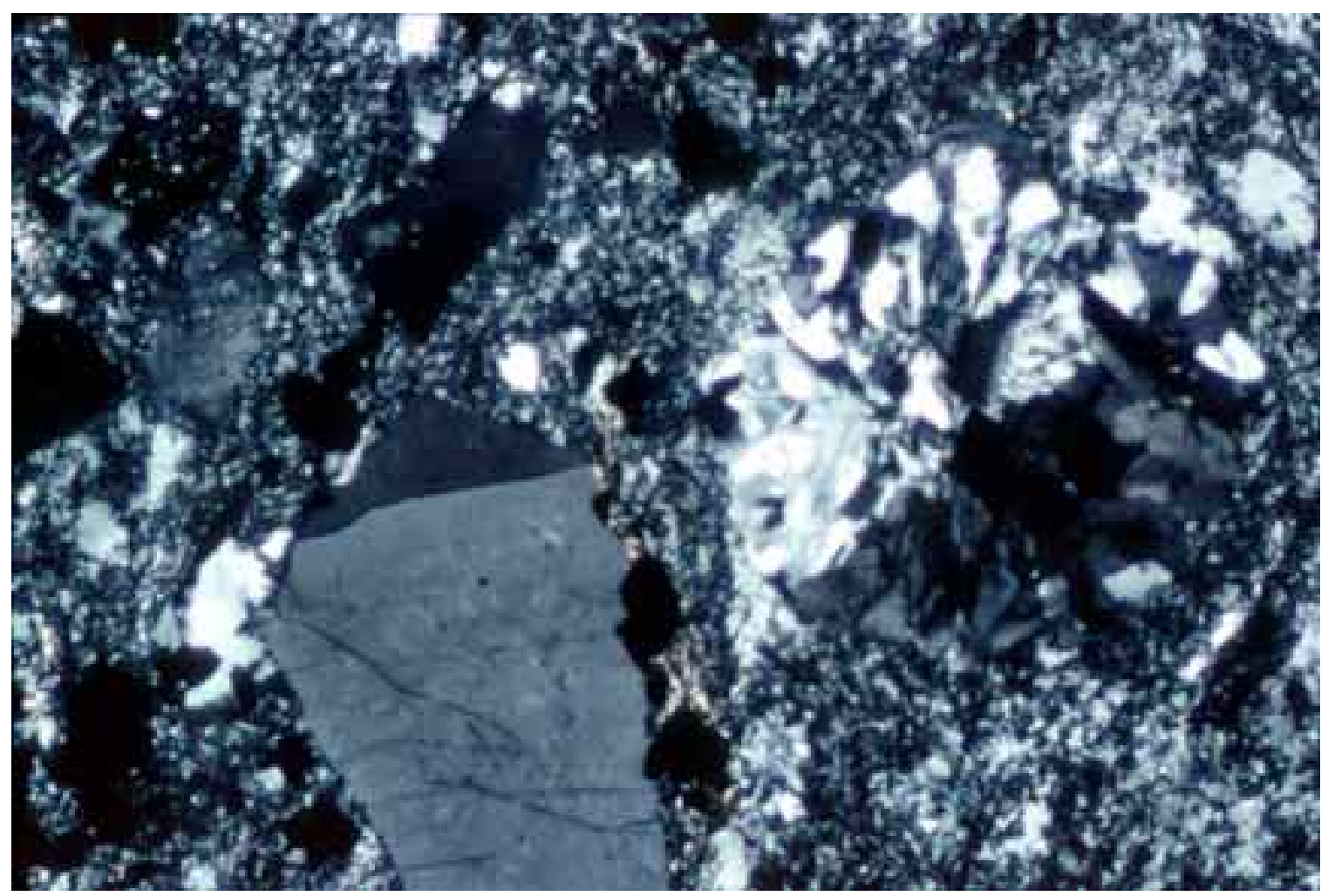

Figure 11. Transmitted light photomicrograph (crossed polars) of Permian-aged metarhyolite. A pyroclastic origin for the metarhyolite is suggested by: 1) the presence of an approximately 1-mm granophyre clast (right-hand half of photo); 2) evidence of broken phenocrysts; and 3) the absence of glomerocrysts, common in lava flows or shallow intrusions. Sample 96ADb 47b; width of photo $0.86 \mathrm{~mm}$.

\section{Late Mississippian age for deposition and mineralization of Chena Slate Belt and Liberty area quartzites}

$\mathrm{New} \mathrm{Pb}$ isotopic data for syngenetic(?) galena collected in mineralized drill core from the CSB and from sphalerite-bearing quartzite in the Liberty area indicate a Devono-Mississippian age of mineralization (fig. 12). In addition, an Early Mississippian (346.4 $\pm 1 \mathrm{Ma}$ ) protolith age for the CSB is indicated by a newly determined concordant U-Pb zircon crystallization age for a felsic metatuff layer within carbonaceous argillite in the eastern part of the CSB (fig. 2). These new ages support correlation of the black quartzite unit with both the Devono-Mississippian Nasina assemblage in Yukon as proposed by Mortensen (1992) and Foster (1992), and with the Keevy Peak Formation in the Alaska Range as proposed by Smith and others (1994). 


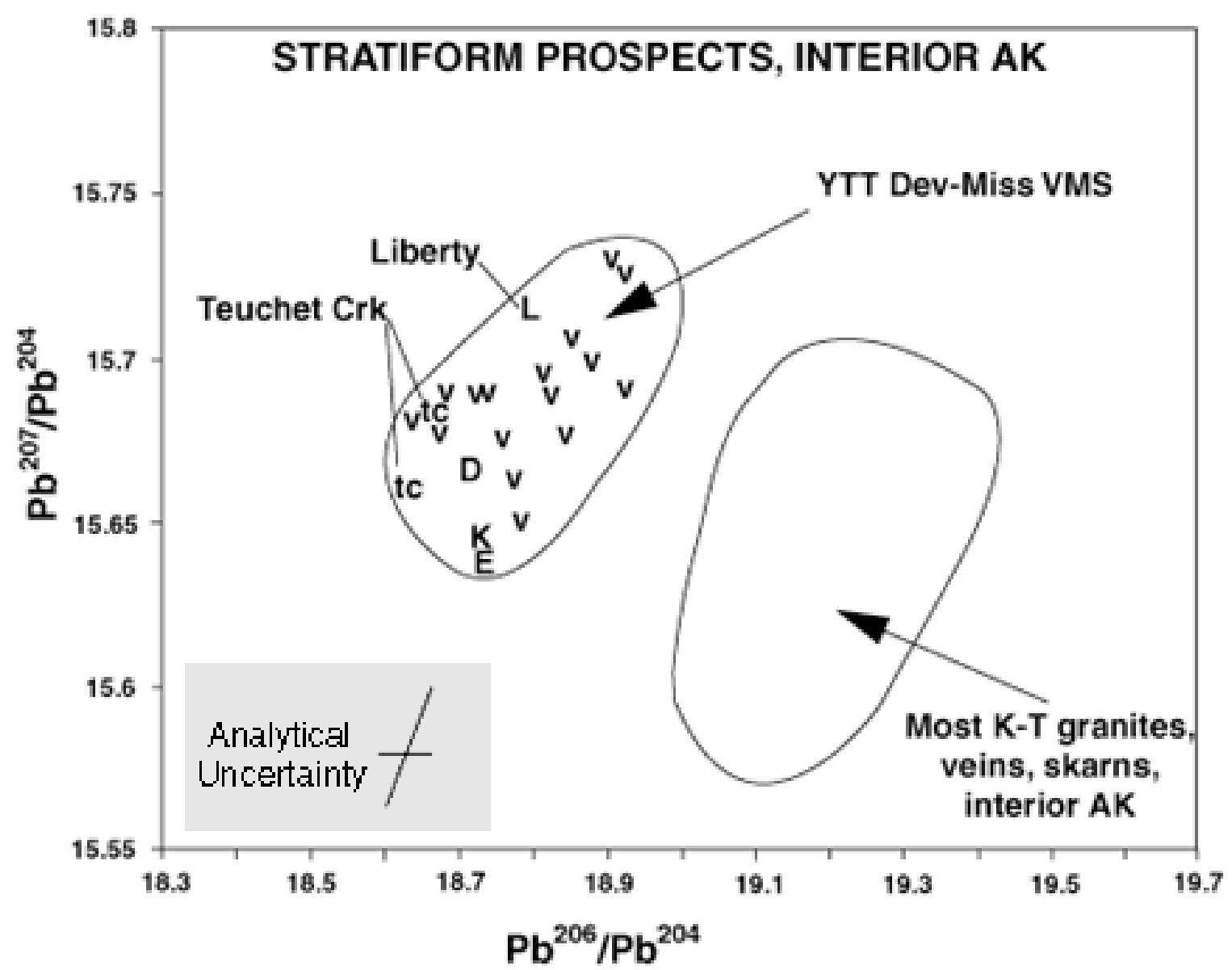

Figure 12. Lead isotopic data for sulfides from east-central Alaska (published data from Church and others, 1987, and Newberry and others, 1997; unpublished 1997 data for galena from Chena Slate Belt (Teuchet Creek drill core) and sphalerite from quartzite in Liberty area from J.K. Mortensen; Abbreviations: v, VMS deposits of the Bonnifield District, Alaska Range; K, Lloyd Prospect, Kantishna; E, mineralized boulder in dredge tailings, Chatanika eclogite terrane; D, Deer Creek, Eagle area.

\section{Conclusions}

1. A syngenetic origin for the sulfides in Nasina assemblage metasedimentary rocks in the CSB and the Liberty areas is indicated by:

- Devono-Mississippian Pb isotopic model ages of stratiform galena and U-Pb zircon crystallization ages of interlayered felsic tuffs.

- finely laminated to locally massive sulfide textures parallel to metamorphic foliation and compositional layering in the graphitic rocks of the CSB.

- the high $\mathrm{SiO}_{2}$ and locally high $\mathrm{Ba}$ contents of the buff-colored, sphalerite- and galenabearing quartzite layers within the carbonaceous sequence in the Liberty area. These layers may represent diagenetically altered and subsequently metamorphosed chemical precipitates that originally formed on the seafloor.

2. Mineralization in Nasina-age rocks of the CSB and the Liberty area may be similar in age and tectonic and (or) sedimentary setting to sediment-hosted $\mathrm{Zn}-\mathrm{Pb}$ deposits in the Selwyn 
Basin-Kechika Trough farther east that occur in fine to coarse black clastic rocks of the Middle Devonian to Mississippian Earn Group.

3. The variety of metals and host rocks at the Lead Creek prospect may indicate multiple episodes of mineralization. $\mathrm{Pb}$ - and Ag-enriched siliceous nodules in carbonaceous schist and metachert are perhaps of diagenetic origin. However, the presence of a feldspar porphyry dike anomalous in $\mathrm{Pb}$ and $\mathrm{As}$, the high $\mathrm{Pb}, \mathrm{Sb}$ and $\mathrm{As}$ in oxidized material, and the presence of quartzgalena veins, contact metamorphism and sulfide-bearing intrusions in the immediate area suggest that some metals were remobilized or introduced during a later magmatic hydrothermal event.

4. The discovery of a Permian-age metarhyolite in the Liberty area expands the potential for stratiform mineralization to include Permian VMS deposits.

\section{Acknowledgments}

Charlie Bacon and Julie Hunt participated in field work. Lew Calk provided expertise and assistance with electron microprobe analyses. Kurt Friehauf advised the senior author on ore microscopy. Denise Armstrong and Chris Keegan provided office and laboratory assistance. Judy Weathers ably turned the senior author's mock-up into a completed poster for Pathways to Discovery Exploration Methods '98 at Cordilleran Roundup. Mike Diggles then turned the poster into the web page you are now viewing.

\section{References}

Church, S.E., Delavaux, M.H., and Gray, J.E., 1987, Pb-isotope base for sulfides from Alaska: U.S. Geological Survey Open-File Report 87-259, 44 p.

Dusel-Bacon, C., Bressler, J.R., Takaoka, H., Mortensen, J.K., Oliver, D.H., Leventhal, J.S., Newberry, R.J., and Bundtzen, T.K., 1997, Stratiform massive sulfides in the YukonTanana Upland of Alaska: Are they there? [abs.]: Abstracts for the Alaska Miners Association 1997 Meeting, Anchorage, Alaska, p. 24-26.

, 1998a, Stratiform zinc-lead mineralization in Nasina assemblage rocks of the YukonTanana Upland in east-central Alaska [abs.]: Pathways '98, Extended Abstracts Volume: British Columbia \& Yukon Chamber of Mines, p. 170-173.

Dusel-Bacon, C., Wooden, J.L., Mortensen, J.K., Bressler, J.R., Takaoka, H., Oliver, D.H., Newberry, R., and Bundtzen, T.K., 1998b, Metamorphic-hosted mineralization in the Yukon-Tanana Upland, Alaska [abs.]: Extended abstracts of the 16th Biennial Conference on Alaskan Mining, March 2-7, 1998, Fairbanks, Alaska Miners Association, p. 16-18.

Foster, H.L., 1992, Geologic Map of the eastern Yukon-Tanana Region, Alaska: U.S. Geological Survey Open-File Report 92-313, 26 p.

Hunt, J.A., 1997, Massive sulphide deposits in the Yukon-Tanana and adjacent terranes. in: Yukon exploration and Geology, 1996, Exploration and Geological Services Division, Yukon, Indian and Northern Affairs Canada, p. 35-45.

Menzie, W.D., and Foster, H.L., 1978, Metalliferous and selected nonmetalliferous mineral resource potential in the Big Delta quadrangle, Alaska: U.S. Geological Survey Open-File Report 78-529D.

Mortensen, J.K., 1988, Geology Southwestern Dawson Map area: Geological Survey of Canada Open-File 1927, scale 1:250,000.

Mortensen, J.K., 1992, Pre-mid-Mesozoic tectonic evolution of the Yukon-Tanana terrane, Yukon and Alaska: Tectonics, v. 11, p. 836-853.

Murphy, D.C., and Abbott, G., 1995, Northern Yukon-Tanana terrane: The equivalent of Yukon's western Selwyn Basin offset along the Tintina fault?: Geological Society of America Abstracts with Programs, v. 27, no. 5, p. 26.

Newberry, R.J., Crafford, T.C., Newkirk, S.R., Young, L.E., Nelson, S.W., and Duke, N.A., 1997, Volcanogenic massive sulfide deposits of Alaska: Economic Geology Monograph 9, p. $120-150$. 
Schmidt, J.M., 1997, Shale-hosted Zn-Pb-Ag and barite deposits of Alaska: Economic Geology Monograph 9, p. 35-65.

Smith, T.E., Robinson, M.S., Weber, F.R., Waythomas, C.W., and Reifenstuhl, R.R., 1994, Geologic map of the upper Chena River area, eastern Interior Alaska: Alaska Division of Geological and Geophysical Surveys Professional Report 115, scale 1:63,360, 19 p.

U.S. Bureau of Mines, 1995, Final Report of the Mineral Resource Evaluation of the Bureau of Land Management Black River and Fortymile River Subunits: U.S. Bureau of Mines Open-File Report 79-95, 69 p.

Weber, F.R., Foster, H.F., Keith, T.E.C., and Dusel-Bacon, Cynthia, 1978, Preliminary geologic map of the Big Delta quadrangle, Alaska: U.S. Geological Survey Open-File Report 78-529-A, scale 1:250,000.

To contact the senior author, email Cynthia Dusel-Bacon (cdusel@usgs.gov). 